\title{
Design, Synthesis, Molecular Docking, ADME and Biological Evaluation Studies of Some New 1,3,4-oxadiazole Linked Benzimidazoles as Anticancer Agents and Aromatase Inhibitors
}

ulviye acar çevik ( $\square$ uacar@anadolu.edu.tr )

Anadolu Universitesi https://orcid.org/0000-0003-1879-1034

Ismail Celik

Erciyes Universitesi

Ayşen IŞIK

Selçuk Üniversitesi: Selcuk Universitesi

Yusuf Özkay

Anadolu Universitesi

Zafer Asım Kaplancıkı

Anadolu Universitesi

Research Article

Keywords: Benzimidazole, 1,3,4-oxadiazole, anticancer, aromatase, docking

Posted Date: October 20th, 2021

DOl: https://doi.org/10.21203/rs.3.rs-975581/v1

License: (c) (i) This work is licensed under a Creative Commons Attribution 4.0 International License. Read Full License 


\section{Abstract}

In this study, due to the potential anticancer effects of the benzimidazole ring system, a series of benzimidazole-1,3,4-oxadiazole derivatives were synthesized and characterized by ${ }^{1} \mathrm{H} \mathrm{NMR},{ }^{13} \mathrm{C} N \mathrm{NR}$, and MS spectra analyses. In the in vitro anticancer assay, all the compounds tested anticancer activities using MTT-based assay against five cancer cell lines (MCF-7, A549, HeLa, C6, and HepG2). Among them, compound $\mathbf{5 a}$ exhibited the most potent activity with $\mathrm{IC}_{50}$ values of $5,165 \pm 0,211 \mu \mathrm{M}$ and $5,995 \pm 0,264 \mu \mathrm{M}$ against MCF-7 and HepG2 cell lines. Compound 5a was included in the BrdU test to determine the DNA synthesis inhibition effects for both cell types. Furthermore, compound $\mathbf{5} \mathbf{c}$ was also found to be more effective than doxorubicin on the HeLa cell line. The selectivity of anticancer activity was evaluated in NIH3T3 (mouse embryo fibroblast cell line) cell line. In vitro, enzymatic inhibition assays of aromatase enzyme were performed for compound $\mathbf{5 a}$ acting on the MCF-7 cell line. For compound $\mathbf{5 a}$, in silico molecular docking against aromatase enzyme was performed to determine possible protein-ligand interactions and binding modes.

\section{Introduction}

Cancer is characterized as the uncontrolled growth of abnormal cells anywhere in the body, is the second leading cause of death worldwide after cardiac disease [1-4]. There are more than a hundred drugs for the cure of cancer. However, drug resistance, side effects, low selectivity, and severe toxicity are the major disadvantages of current drugs. Therefore, there is an urgent need to develop new anticancer drugs with great efficiency and high specificity [5-7].

Estrogen is biosynthesized from androgens by a cytochrome P450 aromatase which has been implicated in numerous diseases including breast cancers. Overexpression of aromatase has been noted in breast cancer cases. Therefore, aromatase is the target enzyme for the treatment of hormone-dependent breast cancer [8-10]. Third-generation aromatase inhibitors (non-steroidal aromatase inhibitors) among aromatase inhibitors, which are divided into three classes according to their clinical development, are used as first-line therapy in the treatment of breast cancer in both early and advanced tumors (Figure 1a) [11].

In the field of drug discovery, especially in cancer research, nitrogen-containing heterocyclic rings are extensively investigated [5]. Benzimidazole, is an important pharmacophore and a privileged structure in medicinal chemistry, especially for anti-cancer activity. It is observed that hydrogen bond donor and acceptor sites, that is, N1 and N3 in the benzimidazole core, play a critical role in binding to the biological targets [12]. In recent studies, potential anticancer activity has been noted in compounds to which benzimidazole is linked by other heterocyclic rings [13-16]. The benzimidazole ring has been applied to various marketed anticancer drugs such as bendamustine, veliparip, carbendazim, and nocodazole (Figure 1b).

Based on the above affirmative design aspects, as shown in Figure 2, we have synthesized a new series of benzimidazole linked 1,3,4-oxadiazole derivatives which were later confirmed by ${ }^{1} \mathrm{H}$ NMR, ${ }^{13} \mathrm{C} N \mathrm{NMR}$, and mass spectral techniques. All of the synthesized compounds (5a-5f) were tested for their anti-cancer activity against five different cancer lines including A549, MCF-7, HeLa, HepG2, and C6. Moreover, the most active compound against the MCF-7 cell line was screened for inhibition of aromatase enzyme and DNA synthesis inhibition. Then, the in silico aromatase inhibitory activity was performed for compound $5 \mathbf{a}$ acting on the MCF-7 cell line.

\section{Materials And Methods}

\section{Chemistry}

All chemicals employed in the synthetic procedure were purchased from Sigma-Aldrich Chemicals (Sigma-Aldrich Corp., St. Louis, MO, USA) or Merck Chemicals (Merck KGaA, Darmstadt, Germany). ${ }^{13} \mathrm{C}-\mathrm{NMR}(75 \mathrm{MHz})$ and ${ }^{1} \mathrm{H}-\mathrm{NMR}(300 \mathrm{MHz})$ spectra were recorded on digital FT-NMR spectrometer (Bruker Bioscience, Billerica, MA, USA). Coupling constants (J) were reported as Hertz. Splitting patterns were designated as follows: s: singlet; $d$ : doublet; t: triplet; m: multiplet in the NMR spectra. Melting points were recorded with an MP90 digital melting point apparatus (Mettler Toledo, $\mathrm{OH}, \mathrm{USA}$ ) and were uncorrected. $\mathrm{M}+1$ peaks were determined by Shimadzu LC/MS ITTOF system (Shimadzu, Tokyo, Japan). For thin-layer chromatography (TLC) was performed on Silica Gel 60 F254 TLC plates (Merck KGaA, Darmstadt, Germany). 
Compounds $1 \mathrm{a}-1 \mathrm{c}$ were prepared by the method of the previous study [15]. Sodium disulfide $(0.03 \mathrm{~mol}, 5.7 \mathrm{~g})$ and 4 -substituted benzaldehyde $(0.03 \mathrm{~mol})$ in DMF were treated under microwave irradiation (Anton-Paar Monowave 300 ) at $240{ }^{\circ} \mathrm{C}$ and 10 bar for $5 \mathrm{~min}$. After then, 3,4-diamino benzoic acid $(0.03 \mathrm{~mol}, 4.56 \mathrm{~g})$ was added and kept under the same reaction conditions.

Synthesis of 2-chloro-1-(4-sübstitüepiperaz-1-yl) ethan-1-one derivatives (1d - 1h )

4-Substituted piperazine derivatives were synthesized by the acetylation method applied in the previous study [15].

Synthesis of Methyl 2-(4-substitutedphenyl)-1H-benzo[d]imidazole-6-carboxylate derivatives (2a -2c )

Compounds (1a-1c) $(0.025 \mathrm{~mol})$, methanol, and a catalytic amount of sulfuric acid were reflux for 72 hours. Then the precipitate was filtered off [15].

\section{Synthesis of 2-(4-Substitutedphenyl)-1H-benzo[d]imidazole-6- carbohydrazide derivatives (3a-3c)}

Compounds $(2 \mathrm{a}-2 \mathrm{c})(0.018 \mathrm{~mol})$ and excess of hydrazine hydrate $(5 \mathrm{~mL})$ were placed in the same vial and ethanol $(15 \mathrm{~mL})$ was added. The mixture was treated under microwave irradiation under the same reaction conditions. When the reaction was completed, the mixture was poured into iced water, the product was filtered [15].

Synthesis of 2-((4-Substitutedphenyl)-(6-(5-mercapto-1,3,4-oxadiazol-2-yl)-1H-benzo [d]imidazole derivatives (4a -4c)

Compounds (4a-4c) derivatives were prepared in the previous study [15]. A mixture of hydrazide derivatives (3a-3c) (0.01mol), $\mathrm{NaOH}(0.01 \mathrm{~mol}, 0.4 \mathrm{~g})$, carbon disulfide $(0.01 \mathrm{~mol}, 0.60 \mathrm{~mL})$ and and ethanol is heated under reflux with stirring. The residue is dissolved in water and then acidified with dilute hydrochloric acid (10\%). The resulting precipitate is filtered, washed with water, and dried.

General synthesis method of target compounds ( $5 \mathrm{a}-5 \mathrm{f}$ )

Compounds (4a-4c) $(0.001 \mathrm{~mol})$, potassium carbonate $(0.001 \mathrm{~mol}, 0.138 \mathrm{~g})$, acetylated piperazine $(0.0015$ mol $)$ derivatives and acetone were stirred and heated under reflux for $6 \mathrm{~h}$. After TLC control, the solvent was evaporated, the residue was washed with water, dried (5a-5f) [15].

2-((5-(2-(4-Hydroxyphenyl)-1H-benzo[d]imidazol-6-yl)-1,3,4-oxadiazol-2-yl)thio)-1-(4-(cyclohexyl) )piperazin-1-yl)-ethan-1-one (5a): Yield: $72 \%$, M.P. $=167.7-169.4{ }^{\circ} \mathrm{C} .{ }^{1} \mathrm{H}-\mathrm{NMR}\left(300 \mathrm{MHz}, \mathrm{DMSO}_{\mathrm{g}}\right)$ : $\delta=1.02-1.07$ (4H, m, -cyclohxyl CH), 1.52-1.56 (3H, m, -cyclohxyl $\mathrm{CH}), 1.71-1.75(3 \mathrm{H}, \mathrm{m}$, -cyclohxyl CH), $2.42(1 \mathrm{H}, \mathrm{s},-$ cyclohxyl $\mathrm{CH}), 3.42-3.44(4 \mathrm{H}, \mathrm{m}$, piperazine), 3.47-3.50 (4H, m, piperazine), 4.55 $(2 \mathrm{H}, \mathrm{s},-\mathrm{CH} 2), 6.93-6.95\left(2 \mathrm{H}, \mathrm{m}, 1\right.$,4-disubstituted benzene), 7.63-7.65 $(1 \mathrm{H}, \mathrm{m}$, benzimidazole- $\mathrm{C} 4), 7.79\left(1 \mathrm{H}, \mathrm{dd}, J_{1}=8.34 \mathrm{~Hz}, J_{2}=1.35\right.$ $\mathrm{Hz}$, benzimidazole-C5), 7.80 (1H, s, benzimidazole-C7), 8.07-8.08 (2H, m, 1,4-disubstituted benzene). ${ }^{13} \mathrm{C}-\mathrm{NMR}$ (75 MHz, DMSO$\left.d_{6}\right): \delta=25.26,25.66,26.14,28.45,28.67,36.99,43.83,45.83,48.47,48.92,72.71,116.22,116.27,116.71,119.36,119.75,120.78$, 121.07, 128.85, 129.04, 153.88, 159.96, 160.22, 165.01, 179.44. HRMS (m/z): $[\mathrm{M}+\mathrm{H}]^{+}$calcd for $\mathrm{C}_{27} \mathrm{H}_{30} \mathrm{~N}_{6} \mathrm{O}_{3} \mathrm{~S}: 519.2173$; found: 519.2173.

2-((5-(2-(4-Hydroxyphenyl)-1H-benzo[d]imidazol-6-yl)-1,3,4-oxadiazol-2-yl)thio)-1-(4-(4) -fluorophenyl)-piperazin-1-yl)-ethane-1-one (5b): Yield: 74 \%, M.P.= 116.5-117.8 ${ }^{\circ} \mathrm{C} .{ }^{1} \mathrm{H}-\mathrm{NMR}\left(300 \mathrm{MHz}, \mathrm{DMSO}-\mathrm{d}_{6}\right): \delta=3.08-3.20(4 \mathrm{H}, \mathrm{m}$, piperazine), 3.65-3.70 (4H, m, piperazine), $4.63\left(2 \mathrm{H}, \mathrm{s},-\mathrm{CH}_{2}\right), 6.99-7.11(6 \mathrm{H}, \mathrm{m}$, Aromatic $\mathrm{CH}), 7.86\left(1 \mathrm{H}, \mathrm{d}, \mathrm{J}=8.52 \mathrm{~Hz}\right.$, benzimidazole-C4), $7.99\left(1 \mathrm{H}, \mathrm{dd}, J_{1}=8.52\right.$ $\mathrm{Hz}, J_{2}=1.29 \mathrm{~Hz}$, benzimidazole-C5), $7.80(1 \mathrm{H}, \mathrm{s}$, benzimidazole-C7), $8.20(1 \mathrm{H}, \mathrm{s}$, benzimidazole-C7), $8.27(2 \mathrm{H}, \mathrm{d}, \mathrm{J}=8.73 \mathrm{~Hz}, 1,4-$ disubstituted benzene), $10.79(1 \mathrm{H}, \mathrm{s}, \mathrm{O}-\mathrm{H}) .{ }^{13} \mathrm{C}-\mathrm{NMR}\left(75 \mathrm{MHz}, \mathrm{DMSO}-\mathrm{d}_{6}\right): \delta=37.17,42.00,45.65,49.56,49.94,112.40,115.38$, 115.88 (d, J=21.87 Hz), 116.80, 118.39, 118.49, 119.23, 123.11, 130.59 (d, J=2.05 Hz), 134.70 (d, J= 7.62 Hz), 136,68, 147,78, 
152.30, 155.37, 158.50, 163.98, 164.00 (d, J=228.37 Hz), 165.18. HRMS (m/z): $[M+H]^{+}$calcd for $\mathrm{C}_{27} \mathrm{H}_{23} \mathrm{~N}_{6} \mathrm{O}_{3} \mathrm{FS}: 531.1594$; found: 531.1609 .

2-((5-(2-(4-Methoxyphenyl)-1 H-benzo[d]imidazol-6-yl)-1,3,4-oxadiazol-2-yl)thio)-1-(4-(cyclohexyl) )piperazin-1-yl)-ethan-1-one (5c): Yield: $78 \%$, M.P. $=177.3-178.8^{\circ} \mathrm{C} .1 \mathrm{H}-\mathrm{NMR}\left(300 \mathrm{MHz}, \mathrm{DMSO}-\mathrm{d}_{6}\right): \delta=1.19-1.22(3 \mathrm{H}, \mathrm{m},-$ cyclohxyl CH$), 1.36-1.40$ (4H, m, -cyclohxyl $\mathrm{CH}), 1.55-1.59$ (3H, m, -cyclohxyl CH), 2.07 (1H, s, -cyclohxyl CH), 2.97-2.99 (4H, m, piperazine), 3.14-3.16 (4H, m, piperazine), 3.93 $(3 \mathrm{H}, \mathrm{s},-\mathrm{OCH} 3), 4.63\left(2 \mathrm{H}, \mathrm{s},-\mathrm{CH}_{2}\right), 7.11(2 \mathrm{H}, \mathrm{d}, \mathrm{J}=8.46 \mathrm{~Hz}, 1,4$-disubstituted benzene), $7.69(1 \mathrm{H}, \mathrm{s}$, benzimidazole-C4), $7.74(1 \mathrm{H}, \mathrm{s}$, benzimidazole-C7), $7.80\left(1 \mathrm{H}, \mathrm{dd}, J_{1}=8.40 \mathrm{~Hz}, J_{2}=1.56 \mathrm{~Hz}\right.$, benzimidazole-C5), 8.21-8.25 (2H, m, 1,4-disubstituted benzene). ${ }^{13} \mathrm{C}$ NMR (75 MHz, DMSO-d 6 ): $\delta=24.97,25.32,25.76,26.59,27.69,36.81,45.37,48.19,55.87,59.00,63.63,64.50,114.88,116.75$, $116.97,120.77,122.47,129.01,154.29,161.50,163.07,165.47,166.51,167.02,167.52,178.10$. HRMS (m/z): [M+H] $]^{+}$calcd for $\mathrm{C}_{28} \mathrm{H}_{32} \mathrm{~N}_{6} \mathrm{O}_{3} \mathrm{~S}: 533.2331$; found: 533.2329.

2-((5-(2-(4-Methoxyphenyl)-1H-benzo[d]imidazol-6-yl)-1,3,4-oxadiazol-2-yl)thio)-1-(4-(4) -fluorophenyl)-piperazin-1-yl)-ethane-1-one (5d): Yield: $64 \%$, M.P. $=>300{ }^{\circ} \mathrm{C} .{ }^{1} \mathrm{H}-\mathrm{NMR}\left(300 \mathrm{MHz}, \mathrm{DMSO}-\mathrm{d}_{6}\right): \delta=3.42\left(3 \mathrm{H}, \mathrm{s},-\mathrm{OCH}_{3}\right), 3.48-3.53(8 \mathrm{H}, \mathrm{m}$, piperazine), $4.54(2 \mathrm{H}, \mathrm{s},-$ $\left.\mathrm{CH}_{2}\right), 6.86-6.89(4 \mathrm{H}, \mathrm{m}$, Aromatic $\mathrm{CH}), 7.12(1 \mathrm{H}, \mathrm{d}, \mathrm{J}=8.82 \mathrm{~Hz}$, benzimidazole-C4), $7.30(1 \mathrm{H}$, s, benzimidazole- $\mathrm{C} 7), 7.65-7.66(2 \mathrm{H}, \mathrm{m}$,

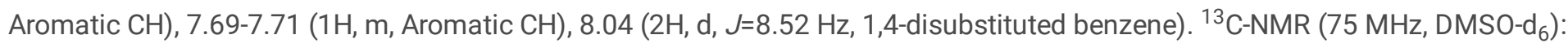
$\delta=37.02,42.22,45.86,52.40,52.91,61.28,113.54,115.39$ (d, J=20.96 Hz), 115.72, 116.65, 128.80, 129.01, 131.18 (d, J= 7.73 Hz), 134.40 (d, J=2.78 Hz), 143.77, 156.07, 156.49, 161.76 (d, J=240.93 Hz), 162.36, 162.86, 165.11, 166.03, 166.79, 168.20. HRMS (m/z): $[\mathrm{M}+\mathrm{H}]^{+}$calcd for $\mathrm{C}_{28} \mathrm{H}_{25} \mathrm{~N}_{6} \mathrm{O}_{3}$ FS: 545.1740; found: 545.1766 .

2-((5-(2-(4-Ethoxyphenyl)-1H-benzo[d]imidazol-6-yl)-1,3,4-oxadiazol-2-yl)thio)-1-(4-cyclohexyl- piperazin-1-yl)-ethane-1-one (5e): Yield: $69 \%$, M.P. $=167.7-168.4{ }^{\circ} \mathrm{C} .{ }^{1} \mathrm{H}-\mathrm{NMR}\left(300 \mathrm{MHz}, \mathrm{DMSO}_{-} \mathrm{d}_{6}\right): \delta=1.19-1.20(3 \mathrm{H}, \mathrm{m},-$ cyclohxyl CH$), 1.35-1.37\left(3 \mathrm{H}, \mathrm{m},-\mathrm{CH}_{3}\right)$, 1.55-1.59 (2H, m, -cyclohxyl CH), 1.75-1.80 (5H, m, -cyclohxyl CH), 2.08 (1H, s, -cyclohxyl CH), 3.12-3.13 (8H, m, piperazine), 4.11 $\left(2 \mathrm{H}, \mathrm{m},-\mathrm{CH}_{2}\right), 4.62\left(2 \mathrm{H}, \mathrm{s},-\mathrm{CH}_{2}\right), 7.09(2 \mathrm{H}, \mathrm{d}, \mathrm{J}=8.88 \mathrm{~Hz}, 1,4$-disubstituted benzene), 7.69-7.74 (1H, m, benzimidazole-C4), $7.79(1 \mathrm{H}$, $\mathrm{dd}, J_{1}=8.40 \mathrm{~Hz}, J_{2}=1.38 \mathrm{~Hz}$, benzimidazole-C5), $8.13(1 \mathrm{H}, \mathrm{s}$, benzimidazole-C7), 7.09 (2H, d, J=8.76 Hz, 1,4-disubstituted benzene). ${ }^{13} \mathrm{C}-\mathrm{NMR}\left(75 \mathrm{MHz}\right.$, DMSO-d $\left.\mathrm{d}_{6}\right): \delta=15.05,25.01,25.36,25.83,26.63,26.69,27.81,36.84,45.41,48.19,49.63,63.55$, $64.47,115.26,116.73,117.11,120.76,122.28,129.02,154.35,160.80,163.07,165.27,165.45,165.54,166.51,167.51$. HRMS (m/z): $[\mathrm{M}+\mathrm{H}]^{+}$calcd for $\mathrm{C}_{29} \mathrm{H}_{34} \mathrm{~N}_{6} \mathrm{O}_{3} \mathrm{~S}: 547.2470$; found: 547.2486 .

2-((5-(2-(4-Ethoxyphenyl)-1 H-benzo[d]imidazol-6-yl)-1,3,4-oxadiazol-2-yl)thio)-1-(4-(4) -fluorophenyl)-piperazin-1-yl)-ethane-1-one (5f): Yield: 78 \%, M.P.= 232.3-234. ${ }^{\circ} \mathrm{C} .{ }^{1} \mathrm{H}-\mathrm{NMR}\left(300 \mathrm{MHz}, \mathrm{DMSO}-\mathrm{d}_{6}\right): \delta=1.35(3 \mathrm{H}, \mathrm{t}, \mathrm{J}=6.90 \mathrm{~Hz},-\mathrm{CH} 3), 3.07-3.20(4 \mathrm{H}, \mathrm{m}$, piperazin), 3.63-3.70 (4H, m, piperazin), $4.10(2 \mathrm{H}, \mathrm{q}, \mathrm{J}=6.93 \mathrm{~Hz},-\mathrm{CH} 2), 4.61\left(2 \mathrm{H}, \mathrm{s},-\mathrm{CH}_{2}\right), 6.97-7.01(4 \mathrm{H}, \mathrm{m}$, Aromatic C-H), 7.02$7.10(2 \mathrm{H}, \mathrm{m}$, Aromatic $\mathrm{C}-\mathrm{H}), 7.52-7.56\left(1 \mathrm{H}, \mathrm{m}\right.$, benzimidazole-C4), $7.58\left(1 \mathrm{H}, \mathrm{dd}, J_{1}=8.37 \mathrm{~Hz}, J_{2}=1.56 \mathrm{~Hz}\right.$, benzimidazole-C5), 8.02 $\left(1 \mathrm{H}, \mathrm{s}\right.$, benzimidazole-C7), 8.17(2H, d, $=8.82 \mathrm{~Hz}, 1,4$-disubstituted benzene). ${ }^{13} \mathrm{C}-\mathrm{NMR}\left(75 \mathrm{MHz}, \mathrm{DMSO}-\mathrm{d}_{6}\right): \delta=15.17,36.95$, 42.04, 45.71, 49.44, 49.81, 63.54, 114.23, 114.72, 115.84 (d, J=21.79 Hz), 118.22, 118.32, 128.63, 131.06, 131.20, 131.81, 132.68, 133.26, 134.16, 142.55, 145.93, 148.41, 158.34, 159.53, 163.74 (d, J=239.24 Hz). HRMS (m/z): $[\mathrm{M}+\mathrm{H}]^{+}$calcd for $\mathrm{C}_{29} \mathrm{H}_{27} \mathrm{~N}_{6} \mathrm{O}_{3} \mathrm{FS}$ : 559.1900; found: 559.1922.

\section{Anticancer Activity}

The anticancer activity of compounds $\mathbf{5 a}-\mathbf{5} \mathbf{f}$ was screened according to the MTT assays. The MTT assays were performed as previously described [19-21]. Anticancer activity of final compounds was assessed against five different cancer cell lines A549 (lung carcinoma cell line), HeLa (cervical cell line), MCF-7 (human breast adenocarcinoma cell line), HepG2 (human liver carcinoma cell line), and C6 (rat glioma cell line) cell lines as well as NIH3T3 (mouse embryo fibroblast cell line). Doxorubicin was used as the reference drug in the MTT assays.

\section{Aromatase Inhibition Assay}

This method was carried out according to the kit procedure (BioVision, Aromatase (CYP19A) Inhibitor Screening Kit (Fluorometric). The aromatase inhibition assay was performed as previously described [22-23]. 


\section{DNA Synthesis Inhibition Assay}

The BrdU cell proliferation method was performed to analyze the effects of the active compounds on the proliferation of cancer cells as previously studied [15].

\section{Molecular Docking Analysis}

The human placental aromatase cytochrome P450 protein structure was imported into UCSF Chimera 1.15 software with PDB ID: 3QEM code (https://www.rcsb.org/structure/3EQM) [24]. Heteroatoms other than HEM in the protein crystal structure have been removed. 2D ligand structures were drawn with ChemDraw Professional 17.0 software and minimized 3D structures were created using a universal force field. Protein and ligand structures were converted to pdbqt file format with PyRx 0.8 software. Based on the ASD ligand in the protein crystal structure, active site coordinates were determined as $x: 85.79, y: 54.14$, and $z: 46.05$, and a $20 \star 20 * 20 \AA 33$ grid box was created. A molecular docking study was carried out with AutoDock Vina 1.1.2 [25] via PyRx 0.8 software. Analysis and demonstration of protein-ligand interactions were done with BIOVIA Discovery Studio Visualizer v21.

\section{ADME Prediction}

Computational ADME analysis was performed using SwissADME (http://www.swissadme.ch/) to estimate the physiochemical, lipophilicity, water-solubility, pharmacokinetics, drug-likeness, and medicinal chemistry properties of the compound.

\section{Results And Discussion}

\section{Chemistry}

The synthesis of the target compounds (5a-5f) was shown in Figure 3. In the first step, the compounds 1a-1c derivatives were obtained by heating 4-substituted benzaldehyde with 3,4-diamino benzoic acid in DMF and sodium bisulfite. The compounds (1a-1c) were converted to a methyl ester (2a-2c) by a simple esterification reaction. Then, the appropriate solution of compounds $\mathbf{2 a}-\mathbf{2 c}$ in ethanol (95\%) was treated with hydrazine hydrate to prepare compounds $\mathbf{3 a - 3} \mathbf{c}$. The reaction of hydrazide derivatives (3a-3c) with carbon disulfide in ethanolic potassium hydroxide gave the compounds $4 a-4 c$. At the last reaction step, the compounds $\mathbf{4 a - 4 c}$ were reacted with acetylated piperazine derivatives in acetone to produce target compounds $\mathbf{5 a - 5 f}$. The structures of newly synthesized compounds $(\mathbf{5 a}-\mathbf{5 f})$ were characterized by using various modern analytical techniques like ${ }^{1} \mathrm{H}$ NMR, ${ }^{13} \mathrm{C}$ NMR, and HRMS.

${ }^{1} \mathrm{H}$ NMR spectral analysis of the compounds $\mathbf{5 a - 5 f}$ demonstrated that the $\mathrm{S}-\mathrm{CH}_{2}$ (methylene) protons were signaled between $\delta$ 4.54-4.63 ppm, as a singlet. The protons of piperazine moiety are seen as multiplet at 2.97-3.70 ppm. In the ${ }^{1} \mathrm{H}$ NMR spectrum of the compounds $\mathbf{5 c}$ and $\mathbf{5 d}$ carrying 4-methoxyphenyl group in the second position of the benzimidazole ring, the protons of the methoxy substituent gave a singlet peak at 3.42-3.93 ppm. The $-\mathrm{OC}_{2} \mathrm{H}_{5}$ group of compounds $\mathbf{5 e}$ and $\mathbf{5} \mathbf{f}$ on the phenyl ring, $-\mathrm{OCH}_{2}$ protons were observed at 4.10-4.11 ppm and $\mathrm{CH}_{3}$ protons were observed at 1.35-1.37 ppm. The benzimidazole proton was visualized in the form of doublet's doublet in ${ }^{1} \mathrm{H}$ NMR spectra at around 7.58-7.99, due to $\mathrm{H}-5$ proton. In the ${ }^{13} \mathrm{C}$ NMR, carbon atoms of the compound have similar chemical shift indicated values indicating in the literature. The HRMS analysis confirmed the mass with the calculated values of the target compounds.

\section{Anticancer Activity}

In this study, all compounds were screened for their antiproliferative activity against MCF-7 (human breast adenocarcinoma cell line), A549 (lung carcinoma cell line), HepG2 (human liver carcinoma cell line) HeLa (cervical cell line), and C6 (rat glioma cell line) cell lines as well as NIH3T3 (mouse embryo fibroblast cell line) using MTT assay where doxorubicin was used as reference. Results summarized in Table 1 were expressed as the mean $\mathrm{IC}_{50}$ (half maximal inhibitory concentration) of four independent experiments.

The benzimidazole derivative 5 a possessing cyclohexyl was the most potent compound against MCF-7 $\left(\mathrm{IC}_{50}=5,165 \pm 0,211 \mu \mathrm{M}\right)$ and HepG2 $\left(\mathrm{IC}_{50}=5,995 \pm 0,264 \mu \mathrm{M}\right)$ cell lines. Furthermore, compound 5 a exhibited moderate activity against the other cell lines. 
Compound 5a exhibits high selectivity against MCF7 $(\mathrm{SI}=37,91)$ and HepG2 $(\mathrm{SI}=32,99)$ cell lines between cancer cells and normal cells. The compound $\mathbf{5} \mathbf{c}$ was the most active agent against the HeLa cell line $\left(\mathrm{IC}_{50}=7,316 \pm 0,276 \mu \mathrm{M}\right)$. Furthermore, compound $\mathbf{5} \mathbf{c}$ exhibited moderate activity against C6, HepG2, and MCF7 cell lines and poor selectivity. Besides, among compounds 5a-5f, compound $\mathbf{5 f}$ exhibited similar anticancer activity to doxorubicin against the HeLa cell line with $I_{50}$ values of $15,269 \pm 0,850 \mu \mathrm{M}$. To determine the side effects of compounds $\mathbf{5 a}$ and $\mathbf{5 c}$, which are effective on cancer cell lines, their cytotoxic effects on the NIH3T3 cell line were investigated (Table 1).

Table 1

$\mathrm{IC}_{50}$ values $(\mu \mathrm{M})$ of the compounds $5 \mathrm{a}-5 \mathrm{f}$.

\begin{tabular}{|llllllll|}
\hline Comp & A549 & MCF-7 & C6 & HepG2 & HeLa & NIH3T3 & $\begin{array}{c}\text { Aromatase } \\
\text { Inhibition }\end{array}$ \\
\hline $\mathbf{5 a}$ & $44,256 \pm 1,712$ & $\mathbf{5 , 1 6 5 \pm 0 , 2 1 1}$ & $36,645 \pm 0,615$ & $\mathbf{5 , 9 9 5 \pm 0 , 2 6 4}$ & $19,906 \pm 0,603$ & $195,788 \pm$ & $2,314 \pm 0,103$ \\
\hline $\mathbf{5 b}$ & $\geq 100$ & $25,886 \pm 0,877$ & $82,372 \pm 2,344$ & $\geq 100$ & $\geq 100$ & - & - \\
\hline $\mathbf{5 c}$ & $\geq 100$ & $25,432 \pm 1,186$ & $40,265 \pm 0,965$ & $17,193 \pm 0,784$ & $7,316 \pm 0,276$ & $39,105 \pm 1,02$ & - \\
\hline $\mathbf{5 d}$ & $\geq 100$ & $\geq 100$ & $\geq 100$ & $\geq 100$ & $\geq 100$ & - & - \\
\hline $\mathbf{5 e}$ & $\geq 100$ & $\geq 100$ & $\geq 100$ & $\geq 100$ & $\geq 100$ & - & - \\
\hline $\mathbf{5 f}$ & $\geq 100$ & $\geq 100$ & $\geq 100$ & $\geq 100$ & $15,269 \pm 0,850$ & - & - \\
\hline Dox. & $12,420 \pm 0,521$ & $10,525 \pm 0,472$ & $28,690 \pm 1,228$ & $16,482 \pm 0,804$ & $14,280 \pm 0,704$ & $1110,80 \pm 8,254$ & - \\
\hline Let. & - & - & - & - & - & - & $0.032 \pm$ \\
\hline
\end{tabular}

A549: lung carcinoma cell line, HepG2: human liver carcinoma cell line, HeLa: cervical cell line, C6: rat glioma cell line, and NIH3T3: mouse embryo fibroblast cell line

According to all results, it can be concluded that 4-hydroxyphenyl and 4-methoxyphenyl enhanced anticancer activity more than 4-methoxyphenyl. The presence of group cyclohexyl at the 4th position of the piperazine scaffold also increased anticancer activity, whereas 4-fluorophenyl moiety at the 4th position of the piperazine ring led to a significant drop in anticancer activity.

\section{Aromatase Inhibition Assay}

The human aromatase inhibitory activity of the synthesized compounds was determined by using an in vitro fluorescence-based assay [Aromatase (CYP19A) Inhibitor Screening Kit (Fluorimetric) BioVision]. The target compound was dissolved in acetonitrile, and the results were compared to letrozole, used as the reference compound. According to the result, compound $\mathbf{5 a}$ causes $50 \%$ aromatase enzyme inhibition effectively at 2,314 $\pm 0,103 \mu \mathrm{M}$ (Table 1).

\section{DNA Synthesis Inhibition Assay}

According to the MTT assay, compound 5a for MCF7 and HepG2 cell lines were selected for the DNA synthesis inhibition assay. MCF-7 and HepG2 cells were incubated with three different concentrations $\left(2 x \mathrm{IC}_{50}, \mathrm{IC}_{50}\right.$, and IC $\left.\mathrm{I}_{50 / 2}\right)$ of the compounds for 24 and $48 \mathrm{~h}$ periods. The tested compounds showed time-and dose-dependent inhibitory activity on DNA synthesis of the tumor cells. Doxorubicin was used as the positive control. Figure 4 shows the DNA \% synthesis inhibitory activity of the compound $\mathbf{5 a}$ and standard drug doxorubicin on MCF7 cells. Compound 5a was found to have 92.44, 82.12, and 75.48 \% DNA synthesis inhibition after $24 \mathrm{~h}$ of incubation whereas the same compound was found to have 44.63,55.71, and $50.54 \%$ DNA synthesis inhibition after $48 \mathrm{~h}$. Figure 5 shows the DNA \% synthesis inhibitory activity of compounds $5 \mathrm{a}$ and standard drug on HepG2 cells. DNA \% inhibition was increased with the increasing incubation period ( $24 \mathrm{~h}$ and $48 \mathrm{~h}$ ).

\section{Molecular Docking Analysis}


Molecular docking analyzes are frequently used in drug design and development stages. It is useful in predicting how the protein and ligand interact at the atomic level $[\mathbf{1 7}, \mathbf{1 8}]$. In this study, the interaction of compound $\mathbf{5 a}$ compound, which is the most active derivative, with the aromatase enzyme was investigated by the molecular docking method. The suitability of the protein crystal structure (PDB ID: 3EQM, resolution: $2.90 \AA$ ) bond angles between the atoms was determined by creating a Ramachandran Plot through the PROCHECK server (https://servicesn.mbi.ucla.edu/PROCHECK/), and it was observed that $98.2 \%$ of the amino acid angles were in the allowed region. Validation of the molecular docking process is important for the success of the study.

Accordingly, the ASD compound, which is the natural ligand of the 3EQM crystal structure, was removed from the area where it was located and re-docked to the active site. The RMSD was measured as $0.46 \AA$ between the crystalline ASD and the docked ASD, and it was concluded that the docking process was successful and made accurate predictions. Then, the synthesized compounds were molecular docking to the active site. As shown in Figure 6, compound $\mathbf{5 a}$ is positioned right next to the HEM structure. As given in Table 2, the compound 5a human placental aromatase enzyme formed hydrogen bonding with residues Arg115, Leu372, Leu477, and Val369 and hydrophobic interactions with some other amino acids at its active site.

Table 2

Details of protein-ligand interactions for compound $\mathbf{5 a}$ in the human placental aromatase active site

\begin{tabular}{|c|c|c|c|c|}
\hline Protein/Enzyme & $\begin{array}{l}\text { Interacting } \\
\text { residues }\end{array}$ & $\begin{array}{l}\text { Distance } \\
(\AA)\end{array}$ & Category & Type \\
\hline $\begin{array}{l}\text { Human placental aromatase cytochrome P450 } \\
\text { 19A1 }\end{array}$ & Arg115 & 2,93 & $\begin{array}{l}\text { Hydrogen } \\
\text { Bond }\end{array}$ & Conventional \\
\hline \multirow[t]{17}{*}{ (PDB: 3EQM) } & Leu372 & 3,10 & $\begin{array}{l}\text { Hydrogen } \\
\text { Bond }\end{array}$ & Conventional \\
\hline & Leu477 & 2,12 & $\begin{array}{l}\text { Hydrogen } \\
\text { Bond }\end{array}$ & Conventional \\
\hline & Val369 & 2,73 & $\begin{array}{l}\text { Hydrogen } \\
\text { Bond }\end{array}$ & Conventional \\
\hline & Thr310 & 3,95 & Hydrophobic & Pi-Sigma \\
\hline & Phe134 & 5,74 & Other & Pi-Sulfur \\
\hline & Phe221 & 4,01 & Hydrophobic & Pi-Pi Stacked \\
\hline & Phe221 & 3,76 & Hydrophobic & Pi-Pi Stacked \\
\hline & His480 & 5,03 & Hydrophobic & $\begin{array}{l}\text { Pi-Pi T- } \\
\text { shaped }\end{array}$ \\
\hline & Ile133 & 4,93 & Hydrophobic & Alkyl \\
\hline & Ile133 & 4,83 & Hydrophobic & Alkyl \\
\hline & Ala306 & 4,47 & Hydrophobic & Alkyl \\
\hline & Val370 & 4,85 & Hydrophobic & Pi-Alkyl \\
\hline & Val313 & 5,21 & Hydrophobic & Pi-Alkyl \\
\hline & HEM600 & 4,33 & Hydrophobic & Pi-Alkyl \\
\hline & HEM600 & 5,00 & Hydrophobic & Pi-Alkyl \\
\hline & HEM600 & 4,43 & Hydrophobic & Pi-Alkyl \\
\hline & HEM600 & 5,16 & Hydrophobic & Pi-Alkyl \\
\hline
\end{tabular}

\section{ADME Prediction}

Many drug molecule candidates remain in phase studies without a drug molecule due to poor ADME properties. Making some theoretical ADME calculations of the designed and newly synthesized compounds can provide convenience in advanced in vitro 
and in vivo studies of the compound. Therefore, some properties of the designed compounds such as physiochemical, lipophilicity, water-solubility, pharmacokinetics, drug-likeness, and medicinal chemistry properties were calculated using SwissADME online tools, and some properties most active compound 5 a was given in Table 3. The molecular weight of compound $5 \mathrm{a}$ is slightly greater than $500(518.63 \mathrm{~g} / \mathrm{mol})$. The logP value is less than 5 in all lipophilicity calculations. Its solubility in water is between moderate and poor. Its gastrointestinal absorption was calculated as low and also not able to pass through the blood-brain barrier. It has the potential to inhibit Cyp enzymes, that is, to interact with other drug molecules. While druglikeness is low according to Ghose and Egan, it is appropriate according to the restrictive rules of Lipinski, Veber, and Muegge. The leadlikeness property shows two deviations from the shortening rules. Other medicinal chemistry parameters are suitable. 
Table 3

Physiochemical, lipophilicity, water-solubility, pharmacokinetics, druglikeness, and medicinal chemistry properties of compound $\mathbf{5} \mathbf{a}$.

\begin{tabular}{|c|c|}
\hline \multicolumn{2}{|l|}{ Physicochemical Properties } \\
\hline Formula & $\mathrm{C}_{27} \mathrm{H}_{30} \mathrm{~N}_{6} \mathrm{O}_{3} \mathrm{~S}$ \\
\hline Molecular weight & $518.63 \mathrm{~g} / \mathrm{mol}$ \\
\hline Num. heavy atoms & 37 \\
\hline Num. arom. heavy atoms & 20 \\
\hline Fraction Csp3 & 0.41 \\
\hline Num. rotatable bonds & 7 \\
\hline Num. H-bond acceptors & 7 \\
\hline Num. H-bond donors & 2 \\
\hline Molar Refractivity & 151.04 \\
\hline TPSA & $136.68 \AA^{2}$ \\
\hline \multicolumn{2}{|l|}{ Lipophilicity } \\
\hline $\log P_{\mathrm{o} / \mathrm{w}}(\mathrm{iLOGP})$ & 3.81 \\
\hline $\log P_{\mathrm{o} / \mathrm{w}}(\mathrm{XLOGP})$ & 4.28 \\
\hline $\log P_{\mathrm{o} / \mathrm{w}}(\mathrm{WLOGP})$ & 3.79 \\
\hline $\log P_{\mathrm{o} / \mathrm{w}}(\mathrm{MLOGP})$ & 2.57 \\
\hline $\log P_{\mathrm{o} / \mathrm{w}}($ SILICOS-IT) & 3.80 \\
\hline Consensus Log $P_{\mathrm{o} / \mathrm{w}}$ & 3.65 \\
\hline \multicolumn{2}{|l|}{ Water Solubility } \\
\hline $\log S(E S O L)$ & -5.69 \\
\hline Solubility & $1.06 \mathrm{e}-03 \mathrm{mg} / \mathrm{ml} ; 2.04 \mathrm{e}-06 \mathrm{~mol} / \mathrm{l}$ \\
\hline Class & Moderately soluble \\
\hline $\log S$ (Ali) & -6.86 \\
\hline Solubility & $7.11 \mathrm{e}-05 \mathrm{mg} / \mathrm{ml} ; 1.37 \mathrm{e}-07 \mathrm{~mol} / \mathrm{l}$ \\
\hline Class & Poorly soluble \\
\hline Log S(SILICOS-IT) & -7.32 \\
\hline Solubility & $2.47 \mathrm{e}-05 \mathrm{mg} / \mathrm{ml} ; 4.76 \mathrm{e}-08 \mathrm{~mol} / \mathrm{l}$ \\
\hline Class & Poorly soluble \\
\hline \multicolumn{2}{|l|}{ Pharmacokinetics } \\
\hline Gl absorption & Low \\
\hline BBB permeant & No \\
\hline P-gp substrate & Yes \\
\hline CYP1A2 inhibitor & No \\
\hline
\end{tabular}

Page 9/14 


\begin{tabular}{|ll|}
\hline \multicolumn{2}{|l|}{ Physicochemical Properties } \\
\hline CYP2C19 inhibitor & Yes \\
\hline CYP2C9 inhibitor & Yes \\
\hline CYP2D6 inhibitor & Yes \\
\hline CYP3A4 inhibitor & Yes \\
\hline Log $K_{\mathrm{p}}$ (skin permeation) & $-6.42 \mathrm{~cm} / \mathrm{s}$ \\
\hline Druglikeness & \\
\hline Lipinski & Yes; 1 violation: MW>500 \\
\hline Ghose & No; 2 violations: MW $>480$, MR $>130$ \\
\hline Veber & No; 1 violation: TPSA $>131.6$ \\
\hline Egan & Yes \\
\hline Muegge & 0.55 \\
\hline Bioavailability Score & \\
\hline Medicinal Chemistry & 0 alert \\
\hline PAINS & 0 alert \\
\hline Brenk & No; 2 violations: MW $>350$, XLOGP3 $>3.5$ \\
\hline Leadlikeness & 4.51 \\
\hline Synthetic accessibility & \\
\hline
\end{tabular}

\section{Conclusion}

In conclusion, we have prepared some new novel benzimidazole-1,3,4-oxadiazole derivatives and their cytotoxicity profile were evaluated on A549, MCF-7, C6, HepG2, and HeLa cell lines. Among these derivatives, compound 5a showed potent anticancer activity against MCF7 $(5,165 \pm 0,211 \mu \mathrm{M})$ and HepG2 $(5,995 \pm 0,264 \mu \mathrm{M})$ cell lines. Compound $5 \mathrm{c}(7,316 \pm 0,276 \mu \mathrm{M})$ showed the most anticancer activity against the HeLa cell line. Furthermore, compound $5 \mathbf{c}(17,193 \pm 0,784 \mu \mathrm{M})$ showed anticancer activity against HepG2 cell line similar to doxorubicin. Compound 5 a tested against human aromatase in an in vitro fluorescence enzymatic assay. Further detailed biological studies including DNA synthesis inhibition assay and aromatase inhibition studies delivered promising results. Molecular docking experiments returned for compound $\mathbf{5 a}$ novel compound a binding mode comparable to letrozole. On the other hand, drug target prediction studies confirmed the role of compound $\mathbf{5 a}$ for aromatase activity inhibition and open new perspectives for further studies.

\section{Declarations}

\section{Conflict of interest statement:}

The authors declared no conflict of interest.

\section{Acknowledgments:}

This study was financially supported by Anadolu University Scientific Projects Fund, Project No: 1706S381. We are grateful to the Doping and Narcotic Compounds Analysis Laboratory for the anticancer activity screening. 


\section{References}

1. Akkoç S (2021) Design, synthesis, characterization, and in vitro cytotoxic activity evaluation of 1,2-disubstituted benzimidazole compounds. J Phys Org Chem 34(1):e4125

2. Pradhan T, Gupta O, Singh G, Monga V (2021) Aurora kinase inhibitors as potential anticancer agents: Recent advances. Eur J Med Chem 221:113495

3. Arya GC, Kaur K, Jaitak V (2021) Isoxazole derivatives as anticancer agent: A review on synthetic strategies, mechanism of action and SAR studies. Eur J Med Chem 221:113511

4. Mustafa M, El-Kardocy A, Mostafa YA (2021) Development of new hetero-steroid hybrids with antiproliferative activity against MCF-7 breast cancer cells. Monatsh Chem 152(1):137-149

5. Avvaru SP, Noolvi MN, More UA et al (2021) Synthesis and anticancer activity of thiadiazole containing thiourea, benzothiazole and imidazo [2, 1-b][1, 3, 4] thiadiazole scaffolds. Med Chem 17:750-765

6. Ayati A, Moghimi S, Toolabi M, Foroumadi A (2021) Pyrimidine-based EGFR TK Inhibitors in Targeted Cancer Therapy. Eur J Med Chem 221:113523

7. Wen X, Zhou Y, Zeng J, Liu X (2020) Recent development of 1,2,4-triazole-containing compounds as anticancer agents. Curr Top Med Chem 20(16):1441-1460

8. Molehin D, Rasha F, Rahman RL, Pruitt K (2021) Regulation of aromatase in cancer. Mol Cell Biochem 476:2449-2464

9. Verma SK, Ratre P, Jain AK, Liang $C$ et al (2021) De novo designing, assessment of target affinity and binding interactions against aromatase: Discovery of novel leads as anti-breast cancer agents. Struct Chem 32(2):847-858

10. Bhuvaneswari K, Sivaguru P, Lalitha A (2020) Synthesis, anticancer evaluation, and docking studies of some novel azo chromene derivatives. J Chin Chem Soc 67(10):1877-1886

11. Ertas M, Sahin Z, Berk B, Yurttas L (2018) Pyridine-substituted thiazolylphenol derivatives: Synthesis, modeling studies, aromatase inhibition, and antiproliferative activity evaluation. Arch Pharma 351(3-4):1700272

12. Sahay II, Ghalsasi PS (2017) Synthesis of new 1,2,3-triazole linked benzimidazole molecules as anti-proliferative agents. Synth Commun 47(8):825-834

13. Husain A, Bhutani M, Parveen S, Khan SA (2021) Synthesis, in vitro cytotoxicity, ADME, and molecular docking studies of benzimidazole-bearing furanone derivatives. J Chin Chem Soc 68(2):362-373

14. Eldehna WM, El Hassab MA, Abo-Ashour MF et al (2021) Development of isatin-thiazolo [3,2-a] benzimidazole hybrids as novel CDK2 inhibitors with potent in vitro apoptotic anti-proliferative activity: Synthesis, biological and molecular dynamics investigations. Bioorg Chem 110:104748

15. Acar Çevik U, Sağlık BN, Osmaniye D et al (2020) Synthesis, anticancer evaluation and molecular docking studies of new benzimidazole-1,3,4-oxadiazole derivatives as human topoisomerase types I poison. J Enzyme İnhib Med Chem 35(1):16571673

16. Caymaz B, Yıldız U, Akkoç S et al (2020) Synthesis, characterization, and antiproliferative activity studies of novel benzimidazole-imidazopyridine hybrids as DNA groove binders. Chemistry Select 5(28):8465-8474

17. Pagadala NS, Syed K, Tuszynski J (2017) Software for molecular docking: a review. Biophys Rev 9(2):91-102

18. Pinzi L, Rastelli G (2019) Molecular docking: Shifting paradigms in drug discovery. Int J Mol Sci 20(18):4331

19. Osmaniye D, Çelikateş BK, Sağlık BN, Levent S et al (2021) Synthesis of some new benzoxazole derivatives and investigation of their anticancer activities. Eur J Med Chem 210:112979

20. Çevik UA, Osmaniye D, Levent S et al (2020) Synthesis and characterization of a new series of thiadiazole derivatives as potential anticancer agents. Heterocycl Comm 26(1):6-13

21. Çevik UA, Osmaniye D, Çavuşoğlu BK et al (2019) Synthesis of novel benzimidazole-oxadiazole derivatives as potent anticancer activity. Med Chem Res 28(12):2252-2261

22. Acar Çevik U, Sağlık BN, Osmaniye D (2020) Synthesis and docking study of benzimidazole-triazolothiadiazine hybrids as aromatase inhibitors. Arch Pharma 353(5):e2000008

Page 11/14 
23. Acar Çevik U, Kaya Çavuşoğlu B, Sağlık BN et al (2020) Synthesis, docking studies and biological activity of new benzimidazole-triazolothiadiazine derivatives as aromatase inhibitor. Molecules 25(7):1642

24. Ghosh D, Griswold J, Erman M, Pangborn W (2009) Structural basis for androgen specificity and oestrogen synthesis in human aromatase. Nature 457(7226):219-223

25. Trott O, Olson AJ (2010) AutoDock Vina: improving the speed and accuracy of docking with a new scoring function, efficient optimization, and multithreading. J Comput Chem 31(2):455-461

\section{Figures}<smiles>CC(C)(C)c1cc(Cn2cncn2)cc(C(C)(C)C#N)c1</smiles>

Anastrozole<smiles></smiles>

Letrozole

(a)

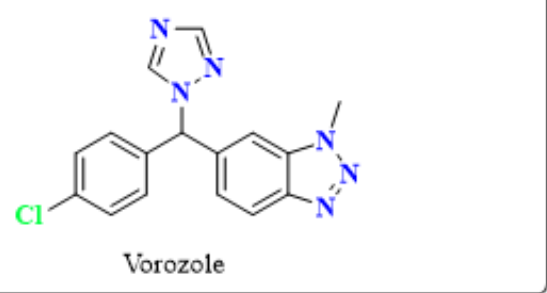<smiles>COC(=O)Nc1nc2cc(C(=O)c3ccc4sccc4c3)ccc2[nH]1</smiles>

(b)

\section{Figure 1}

(a) Third generation of aromatase inhibitors and (b) anticancer drugs containing benzimidazole structure<smiles>[R]c1ccc(-c2nc3ccc(-c4nnc(SCC(=O)N5CCN(C([R2])C)CC5)o4)cc3[nH]2)cc1</smiles>

\begin{tabular}{ccc}
\hline Comp. & $\mathbf{R} \mathbf{1}$ & $\mathbf{R}_{\mathbf{2}}$ \\
\hline $\mathbf{5 a}$ & $-\mathrm{OH}$ & cyclohexyl \\
$\mathbf{5 b}$ & $-\mathrm{OH}$ & 4-fluorophenyl \\
$\mathbf{5} \mathbf{c}$ & $-\mathrm{OCH}_{3}$ & cyclohexyl \\
$\mathbf{5 d}$ & $-\mathrm{OCH}_{3}$ & 4-fluorophenyl \\
$\mathbf{5 e}$ & $-\mathrm{OC}_{2} \mathrm{H}_{5}$ & cyclohexyl \\
$\mathbf{5 f}$ & $-\mathrm{OC}_{2} \mathrm{H}_{5}$ & 4-fluorophenyl \\
\hline
\end{tabular}

\section{Figure 2}

Designed and synthesized compounds as aromatase enzyme inhibitors and hormone-dependent breast anticancer agents 


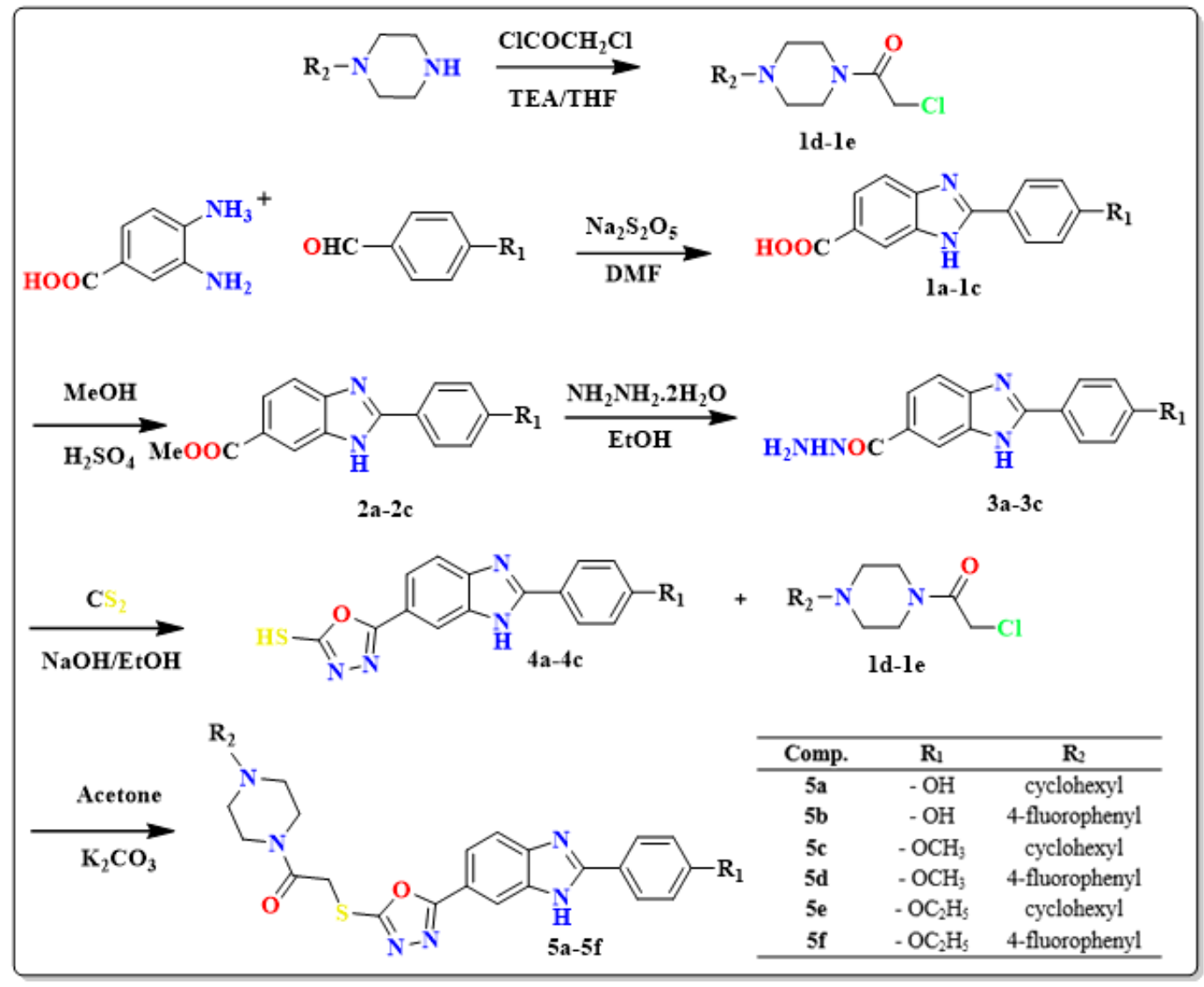

Figure 3

Synthesis pathway of the designed compounds $5 a-5 f$.

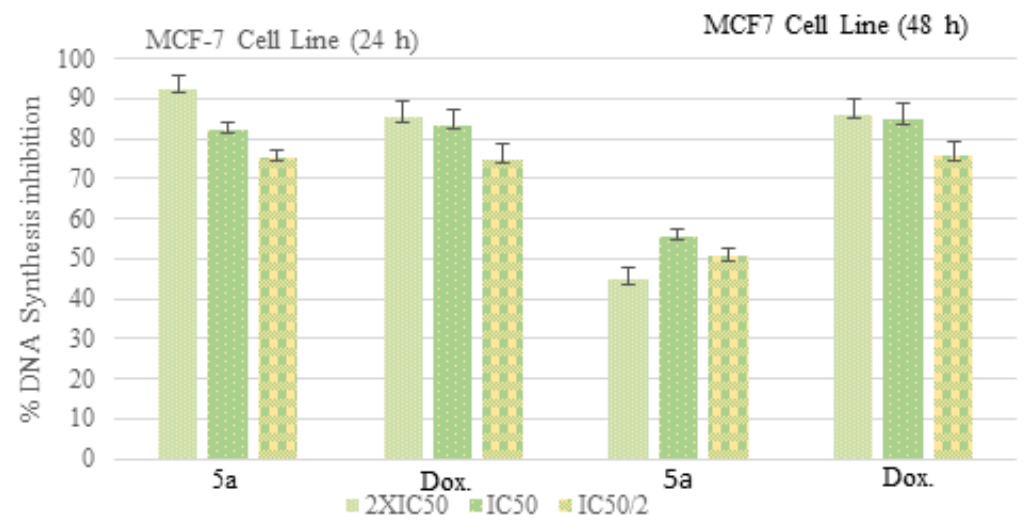

Figure 4

\% DNA synthesis inhibition activities of compound 5a and doxorubicin against MCF-7 cell line for $24 \mathrm{~h}$ and $48 \mathrm{~h}$. 


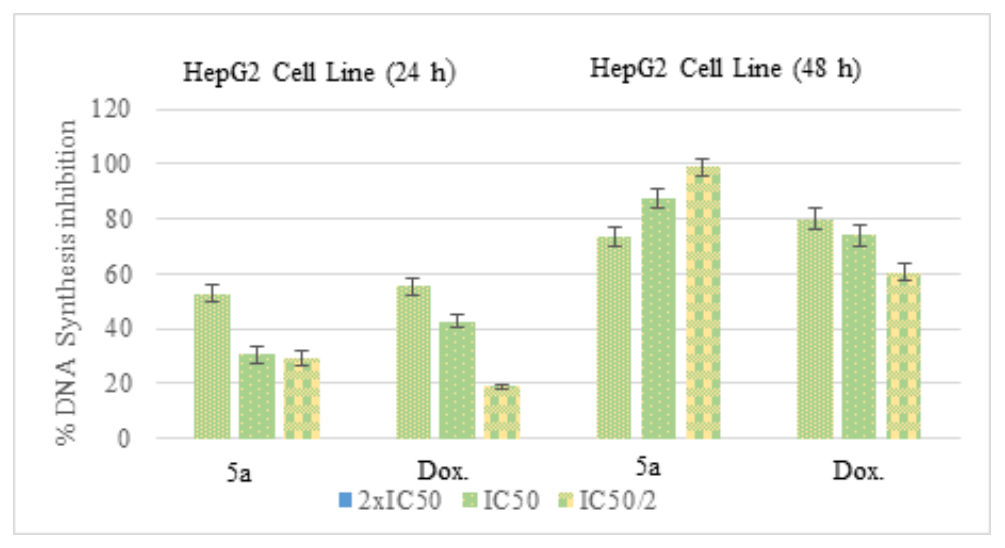

Figure 5

\% DNA synthesis inhibition activities of compound 5a and doxorubicin against HepG2 cell line for $24 \mathrm{~h}$ and $48 \mathrm{~h}$.

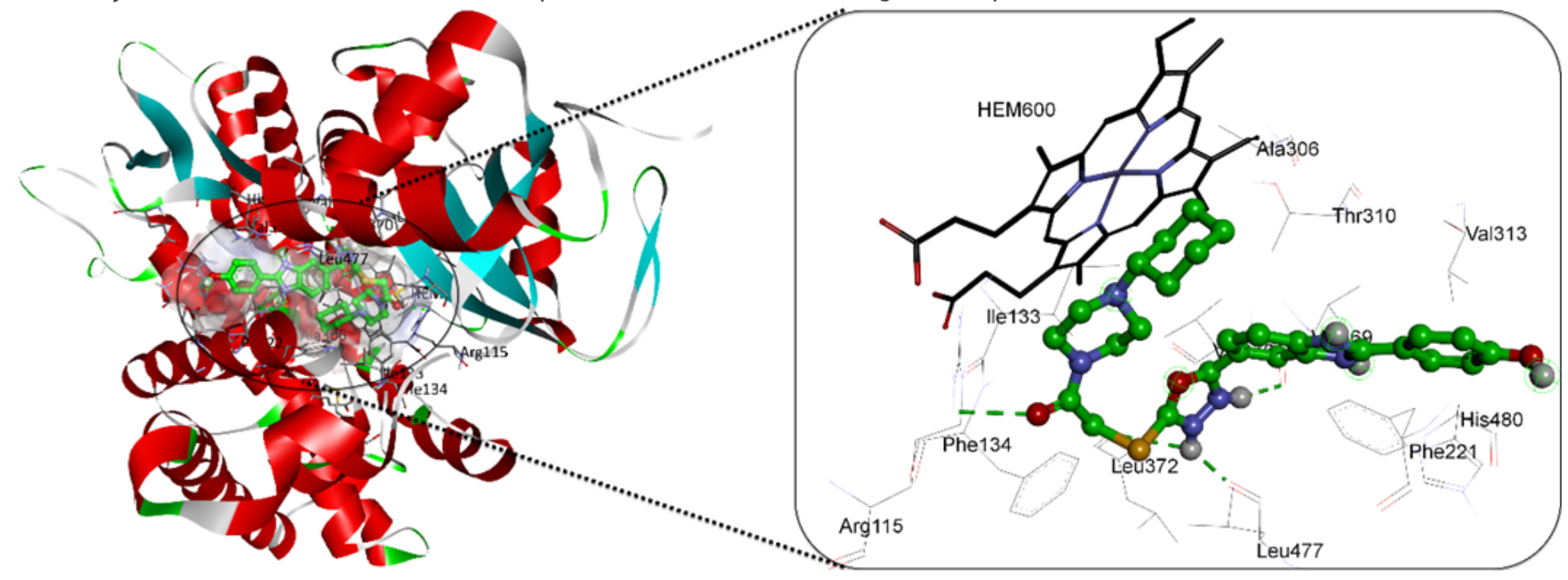

Figure 6

Protein-ligand interaction diagrams of 5a compound at the human placental aromatase cytochrome P450 enzyme active site (PDB ID: 3EQM)

\section{Supplementary Files}

This is a list of supplementary files associated with this preprint. Click to download.

- supp.docx 